ПОКИДА Андрей Николаевич - кандидат социологических наук, директор научно-исследовательского иентра социально-политического мониторинга Института общественных наук Российской академии народного хозяйства и государственной службы при Президенте РФ (119571, Россия, 2. Москва, пр-кт Вернадского, 82; pokida@ranepa.ru)

ЗЫБУНОВСКАЯ Наталья Владимировна - научный сотрудник научно-исследовательского иентра социально-политического мониторинга Института общественных наук Российской академии народного хозяйства и государственной службы при Президенте РФ (119571, Россия, г. Москва, nр-кт Вернадского, 82; nzyb@ranера.ru)

ГАЗИЕВА Инна Александровна - кандидат социологических наук, директор центра общеакадемических образовательных инициатив Института организационного развития и стратегических инициатив Российской академии народного хозяйства и государственной службы при Президенте РФ(119571, Россия, г. Москва, пр-кт Вернадского, 82; gazieva-ia@ranepa.ru)

\title{
САМООЦЕНКИ СОСТОЯНИЯ ЗДОРОВЬЯ ЗАНЯТЫХ РОССИЯН И ОСНОВНЫЕ СПОСОБЫ ЛЕЧЕНИЯ
}

Аннотация. Цель статьи - рассмотреть самооценку здоровья и основные способы лечения занятых россиян в изменившейся реальности в связи с пандемией. Эмпирическую базу исследования составили результаты социологического опроса занятого российского населения, проведенного в 2020 г. $^{1}$ Результаты исследования демонстрируют тенденцию роста позитивных самооценок здоровья занятых россиян за последние десятилетия, что, однако, не распространяется на самое старшее поколение, оценивающее свое здоровье даже хуже, чем в предыдущие годы. Выявлено, что в период экономического кризиса, вызванного пандемией, наиболее сильно в профессиональном и материальном плане пострадали граждане, имеющие какие-либо проблемы со здоровьем. Наблюдается снижение популярности самолечения и рост числа обращений занятого населения в различные медицинские учреждения в случае недомогания (болезни), что обусловливает увеличивающуюся нагрузку на систему здравоохранения.

Ключевые слова: здоровье, пандемия COVID-19, самооценка здоровья, способы лечения, ценности

\section{Введение}

Здоровье является важнейшей общественной и индивидуальной ценностью, значимость которой обусловлена не только необходимостью сохранения человеческого потенциала и увеличения продолжительности жизни, но и тем, что для многих граждан это непременное условие социально активной и счастливой жизни. Например, по данным IPSOS, 92\% опрошенных из 27 стран считают источником счастья здоровье и личное физическое благополучие 2 .

Укрепление здоровья населения на основе формирования здорового образа жизни и охрана здоровья работающего населения входят в число приори-

1 Социологический опрос проведен научно-исследовательским центром социально-политического мониторинга ИОН РАНХиГС с 1 по 10 сентября 2020 г. Опрошены 1205 чел. занятого населения в возрасте 18 лет и старше в 27 субъектах РФ по выборке, репрезентирующей работников основных видов экономической деятельности, занятых на предприятиях различных форм собственности, а также основные социально-демографические характеристики. Опрос проводился методом личного интервью (face to face) по месту работы или жительства респондентов. Данные опроса представлены в сравнении с результатами исследований, проведенных центром ранее по сопоставимой методике.

2 Уровень счастья в период пандемии COVID-19. 2020. - Ipsos. Доступ: https://www.ipsos. com/ru-ru/global-happiness-study-2020 (проверено 15.05.2021). 
тетных направлений решения основных задач развития здравоохранения в Российской Федерации ${ }^{1}$. При этом важно отметить, что здоровье - многоплановое понятие, включающее не только состояние полного физического благополучия, т.е. отсутствие недомоганий и болезней, но также комфортное душевное и социальное самочувствие 2 .

Пандемия COVID-19, с которой столкнулся весь мир в 2020 г., выступила стрессогенным фактором и серьезным катализатором негативных проблем как для физического, так и для душевного и социального самочувствия граждан [Касьянов, Гафиатулина, Васьков 2020; Безуглова 2020]. Пандемический кризис и введенные ограничения на социальные контакты внесли коррективы в устоявшийся образ жизни россиян, спровоцировали выработку новых стандартов поведения. Людям пришлось менять свои привычки - от элементарных гигиенических навыков и физической активности до переустройства режима труда и отдыха, способов социального общения ${ }^{3}$. Довольно серьезная ситуация сложилась на рынке труда. Результаты социологических исследований показывают, что в период карантинных ограничений многие граждане потеряли работу или оказались в неоплачиваемых отпусках [Гимпельсон, Капелюшников 2020].

\section{Ценность здоровья в ряду других социальных ценностей}

Ценностная реальность представляет собой весь мир человека, объединяет все, с чем он сталкивается, что его окружает. Однако ценными для индивида становятся те объекты или явления действительности, которые приобретают для него определенную значимость, важность сообразно его потребностям и интересам [Максименко 2011; Винокурова 2005]. Ценным, как правило, становится то, чего не хватает, или то, чем человек обладает, но чувствует его уязвимость и опасается потерять.

Текущая сложная эпидемиологическая ситуация и различные связанные с ней ограничения существенно изменили привычный образ жизни большинства россиян, что не могло не отразиться на их ценностных приоритетах, в т.ч. на значимости здоровья в ряду других ценностей. Вместе с тем следует учитывать, что, как показывают результаты многолетних исследований, для изменения ценностной структуры требуется довольно длительное время, она весьма консервативна и инерционна. Следует также отметить, что стремление людей придерживаться устоявшихся базовых ценностей, возможно, в какой-то степени способствует их психологическому противостоянию кризису и его последствиям.

В период карантинных ограничений мир людей сузился до своего дома, своей квартиры, люди стали больше внимания уделять семье и семейным ценностям, а простои или закрытие предприятий, вынужденные неоплачиваемые отпуска и риск потери работы усилили потребность в наличии работы

1 Указ Президента РФ от 06.06.2019 N 254 «О Стратегии развития здравоохранения в Российской Федерации на период до 2025 года». Доступ: https://www.garant.ru/products/ ipo/prime/doc/72164534/ (проверено 11.01.2021).

2 Устав ВО3. Доступ: https://www.who.int/governance/eb/constitution/ru/ (проверено 11.01.2021).

3 Защититься от коронавируса! Реально? - ВЦИОМ. 07.04.2020. Доступ: https://wciom. ru/analytical-reviews/analiticheskii-obzor/zashhititsya-ot-koronavirusa-realno (проверено 11.01.2021); Коронавирус меняет повседневные практики россиян. - ВЦИОМ. 10.04.2020. Доступ: https://wciom.ru/analytical-reviews/analiticheskii-obzor/koronavirus-menyaetpovsednevnye-praktiki-rossiyan (проверено 11.01.2021); Adapt! Две трети опрошенных pocсиян носят медицинские маски. - Ipsos. 06.05.2020. Доступ: https://www.ipsos.com/ru-ru/ adapt-dve-treti-oproshennykh-rossiyan-nosyat-medicinskie-maski (проверено 11.01.2021). 
и дохода. Как показывают результаты опросов 2009 и 2020 гг., среди занятого населения увеличилась потребность в материальном обеспечении - с 48,2\% до $54,4 \%$, в профессиональной деятельности - с 18,0\% до 25,0\%, еще более существенно повысилась ценность семьи и детей - с 41,7\% до 52,0\% (см. рис. 1). Закономерно возросла ценность интересного проведения досуга - с 5,8\% до $12,9 \%$.

При этом ожидаемый существенный рост важности ценности здоровья пока не подтвердился. Оценка значимости состояния здоровья осталась на прежнем, хотя и сравнительно высоком уровне. На важность состояния здоровья указали 47,7\% опрошенных в 2009 г. и 47,6\% в 2020 г. Однако наблюдается дифференциация в динамике ответов респондентов в зависимости от возраста: если во всех возрастных группах от 18 до 59 лет за период с 2009 по 2020 г. значимость состояния здоровья в ряду других ценностей несколько снизилась, то в возрастной группе 60 лет и старше она, напротив, увеличилась (с 40,7\% в 2009 г. до 62,3\% в 2020 г.). Отмечаемая тенденция указывает на актуализацию проблемы здоровья у старшего поколения россиян.

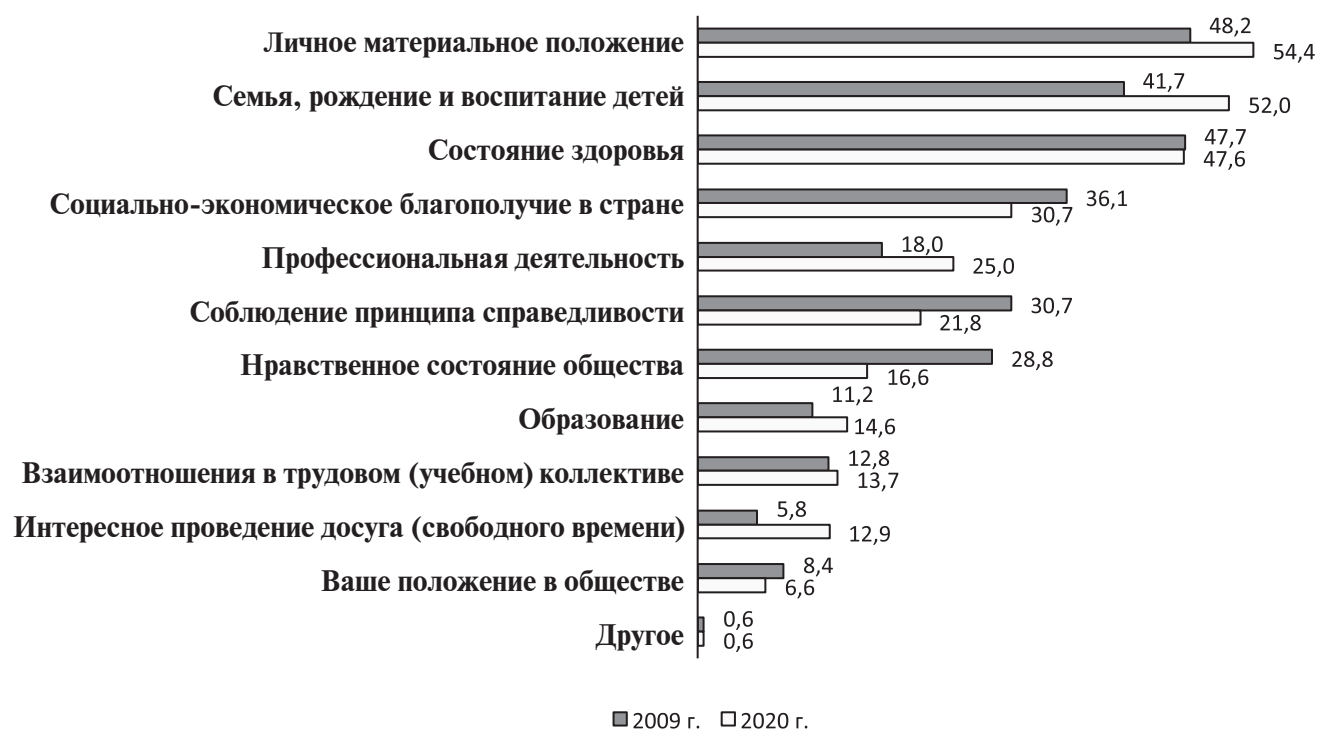

Примечание. Формулировка вопроса: «Какие обстоятельства жизни имеют для Вас очень большое значение?»

Рисунок 1. Ценностная структура занятых россиян (в \% от общего числа опрошенных)

Данные других исследовательских центров также показывают, что ценность здоровья занимает базовую позицию среди различных жизненных обстоятельств россиян. Например, по данным ВЦИОМа (сентябрь 2020 г.), среди различных сторон жизни особую важность для россиян имеют ценности здоровья и безопасности членов своей семьи ${ }^{1}$. Кроме того, получены ответы на открытый вопрос о том, что респонденты стали ценить больше за время карантин-

\footnotetext{
1 Здоровье, безопасность, семья и работа. - ВЦИОМ. 14.10.2020. Доступ: https://wciom. ru/analytical-reviews/analiticheskii-obzor/zdorove-bezopasnost-semya-i-rabota (проверено 11.01.2021)
} 
ных ограничений (режим самоизоляции и различные ограничительные меры, введенные в 2020 г.): $18 \%$ россиян в возрасте от 18 лет и старше стали больше ценить свое здоровье и здоровье своих родных, $12 \%$ - отношения с семьей и родственниками, $10 \%$ - наличие работы ${ }^{1}$.

Стоит, однако, отметить, что ценность здоровья носит для россиян скорее декларируемый характер, поскольку в реальности многие граждане не соблюдают различные составляющие здорового образа жизни. Противоречивое отношение людей к своему здоровью и здоровому образу жизни неоднократно фиксировалось в различных исследованиях [Бойков 2009; Покида, Зыбуновская 2010]. Например, в исследовании ЦИРКОНа, проведенном в 2018 г., ценность здоровья заняла верхнюю позицию в рейтинге ценностей россиян, однако лишь незначительное число опрошенных придерживались формальных критериев ЗОЖ - не употребляли алкоголь, не курили, регулярно занимались спортом ${ }^{2}$.

Пандемия еще более обострила данное противоречие, поскольку осложнила следование общепризнанным нормам здорового образа жизни. По данным ФОМа (май 2020 г.), среди тех, кто соблюдал домашний режим во время самоизоляции, до пандемии зарядку не делали 46\% опрошенных, во время самоизоляции - 52\%; 57\% сообщили, что употребляют алкогольные напитки, $30 \%$ - курят, и 5\% указали, что стали это делать чаще после начала пандемии ${ }^{3}$. Вредные привычки глубоко укоренились в образе жизни россиян, являясь для них способом снятия напряжения, преодоления фрустрации, а стрессовая ситуация пандемических ограничений только усилила в них эту потребность.

\section{Самооценки состояния здоровья занятых россиян}

Самооценка здоровья, другими словами, степень удовлетворенности его состоянием является обобщенным индикатором здоровья. Она свидетельствует как о наличии/отсутствии заболеваний или их симптомов, так и о внутреннем, психологическом самочувствии индивида.

Данные опроса занятого населения показывают, что большая его часть позитивно воспринимает свое здоровье, оценивая его состояние как «хорошее» 4. Об этом заявили 49,7\% опрошенных (см. рис. 2). Более того, за последние 20 лет наблюдается рост числа таких ответов и, соответственно, снижение числа ответов об «удовлетворительном» и «плохом» состоянии здоровья.

Аналогичная тенденция фиксируется и в целом по российскому населению, включая как занятых, так и незанятых граждан. Так, например, по результатам исследования «Российский мониторинг экономического положения и здоровья населения НИУ ВШЭ (RLMS-HSE)», с середины 1990-х гг. наблюдается постепенное увеличение позитивных самооценок здоровья (т.е. как «очень

\footnotetext{
1 Там же.

2 Ценностная солидаризация и общественное доверие в России. - Здоровье. Исследовательская группа «Циркон». Доступ: http://doverie.zircon.tilda.ws/fact\#rec108443117 (проверено 11.01.2021); Ценности россиян. - Исследовательская группа «Циркон». Доступ: http://doverie.zircon.tilda.ws/zennosti (проверено 15.05.2021).

3 Организм на самоизоляции. Что поменялось в привычных практиках заботы о здоровье. - ФОМ. 02.07.2020. Доступ: https://covid19.fom.ru/post/organizm-na-samoizolyacii (проверено 11.01.2021); Разговор о человеке и его отношении к здоровью в пандемических тонах. - ФОМ. 20.07.2020. Доступ: https://covid19.fom.ru/post/razgovor-o-cheloveke-i-egootnoshenii-k-zdorovyu-v-pandemicheskih-tonah_(проверено 11.01.2021).

4 Оценка «хорошее» состояние здоровья рассчитывалась по сумме ответов «очень хорошее» и «хорошее». Аналогично, «плохое» состояние здоровья - по сумме ответов «очень плохое» и «Плохое».
} 


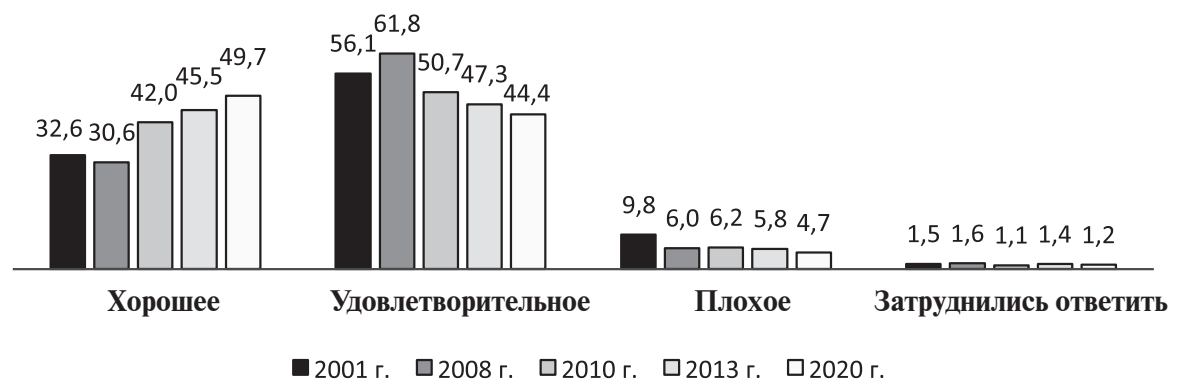

Примечание. Формулировка вопроса: «Как в целом Вы оцениваете состояние своего здоровья?»

Рисунок 2. Изменение самооценок состояния здоровья занятых россиян (в \% от общего числа опрошенных)

хорошее» и «хорошее»): с 25\% в 1994 г. до 37\% в 2017 г. [Козырева, Смирнов 2020].

Результаты исследований Росстата показывают, что в 2008 г. 28,8\% граждан в возрасте 15 лет и старше указали на «очень хорошее» и «хорошее» состояние своего здоровья, в 2013 г. доля таких ответов составила 41,8\%, в 2018 г. $-39,6 \% 1$.

Результаты опросов ВЦИОМа и ФОМа также свидетельствуют о росте положительного восприятия собственного здоровья среди населения ${ }^{2}$.

Самооценка состояния здоровья далеко не всегда основана на данных медицинского освидетельствования - она отражает субъективное восприятие респондентом своего состояния, на что, в частности, влияет конкретная жизненная ситуация, социальное и психологическое самочувствие, возрастные особенности и многие другие факторы. Как отмечает Н.И. Белова, наблюдаемое в последнее время рассогласование неблагоприятных объективных данных, отмечаемых официальной статистикой здравоохранения, и довольно оптимистичных субъективных оценок респондентов связано с увеличивающейся «пластичностью» содержания понятия «здоровье», куда граждане стали вкладывать иной смысл: «не просто отсутствие/наличие болезни, а прежде всего возможность в полной мере выполнять все возложенные на них социальные роли, быть социально мобильным» [Белова 2016: 117]. Тем не менее самооценка выступает достаточно надежным показателем здоровья населения

1 Краткие итоги выборочного обследования «Влияние поведенческих факторов на состояние здоровья населения». 2008. - Росстат. Доступ: https://rosstat.gov.ru/folder/13721 (проверено 11.01.2021); Выборочное наблюдение поведенческих факторов, влияющих на состояние здоровья населения. 2013. - Росстат. Доступ: https://rosstat.gov.ru/free_doc/ new_site/zdor/sdp2013.bfs.publisher/index.html_(проверено 11.01.2021); Выборочное наблюдение поведенческих факторов, влияющих на состояние здоровья населения. 2018. Poccmam. Доступ: https://rosstat.gov.ru/free_doc/new_site/ZDOR/Factors2018_2812/index. html (проверено 11.01.2021).

2 Здоровая нация: миф или реальность? - Пресс-выпуск ВЦИОМ. №2575, 6 мая 2014 г. Доступ: http://www.demoscope.ru/weekly/2014/0597/opros02.php (проверено 11.01.2021); Здоровый образ жизни: мониторинг. - ВЦИОМ. 21.03.2018. Доступ: https://wciom.ru/ analytical-reviews/analiticheskii-obzor/zdorovyj-obraz-zhizni-monitoring-1 (проверено 11.01.2021); Здоровье - высшая ценность. - ВЦИОМ. 09.06.2020. Доступ: https://wciom. ru/analytical-reviews/analiticheskii-obzor/zdorove-vysshaya-czennost (проверено 11.01.2021); Отношение к здоровью. - ФОМ. 29.09.2015. Доступ: https://fom.ru/Zdorove-i-sport/12324 (проверено 11.01.2021); Образ жизни и здоровье. - ФОМ. 12.12.2017. Доступ: https://fom. ru/Zdorove-i-sport/13883 (проверено 11.01.2021). 
и, как показывают различные исследования, достаточно точно отражает реальное положение дел [Кузьмич, Рощин 2007].

Самооценка состояния здоровья сильно зависит от возраста респондента. Если в возрастной группе 18-24 года 77,1\% опрошенных отметили у себя хорошее состояние здоровья, то в группе 40-49 лет таких респондентов оказалось 48,4\%, а в группе 60 лет и старше - только 22,7\%. Стоит отметить, что за последние годы увеличение числа граждан, оценивающих свое здоровье как хорошее, просматривается во всех возрастных группах, кроме самой возрастной - 60 лет и старше. Для данной группы уровень оценок «хорошее состояние здоровья» варьируется в зависимости от года проведения опроса в пределах 20-25\%. Такая ситуация полностью коррелирует с увеличивающейся значимостью ценности здоровья для старшего поколения, что было отмечено выше.

С возрастом не только ухудшается физическое здоровье, но и более остро воспринимаются социальные условия, возрастает значимость психологических факторов, поэтому отсутствие позитивной динамики в самооценках здоровья в самой старшей возрастной группе занятого населения указывает на необходимость усиления мер по повышению уровня и качества жизни таких граждан.

Реже дают своему здоровью хорошие оценки люди с более низким материальным положением, жители сельских поселений, женщины. Отметим, однако, что гендерные различия обусловлены не тем, что здоровье женщин реально хуже, чем у мужчин. По крайней мере, как известно, данные статистики показывают, что средняя продолжительность жизни женщин выше ${ }^{1}$. Скорее они более информированы о фактическом состоянии своего физического здоровья, т.к. чаще посещают врачей и более внимательно и критично к нему относятся, что обусловлено их социальной ролью - родить здоровых детей.

Различия в самооценках здоровья наблюдаются также в зависимости от социально-психологического самочувствия граждан. Так, среди тех граждан, кого тревожит неопределенность будущего, позитивные оценки здоровья встречаются реже. Если об «очень хорошем» здоровье сообщает каждый пятый «оптимист», то доля таких ответов составляет лишь 5\% в группе тех, у кого неопределенность будущего вызывает опасения.

В целом отмечаемое улучшение здоровья населения, во всяком случае по самооценкам опрошенных, обусловлено более бережным отношением к нему. Это выражается в увеличении за допандемические годы числа граждан, которые следят за своим здоровьем ${ }^{2}$ и стараются вести здоровый образ жизни ${ }^{3}$. Социологические исследования показывают, что на состояние здоровья влияет совокупность различных факторов, однако по большей части оно зависит от поведения самого человека [Назарова 2003]. Имеется в виду, что влияние образа жизни людей и конкретных поведенческих стратегий на здоровье более существенно, нежели соот-

1 Продолжительность жизни у мужчин в России на 9,9 года меньше, чем у женщин. - ТАСС. 26.08.2019. Доступ: https://tass.ru/nacionalnye-proekty/6798689 (проверено 11.01.2021).

2 Отношение к здоровью. - ФОМ. 29.09.2015. Доступ: https://fom.ru/Zdorove-i-sport/12324 (проверено 11.01.2021).

3 Краткие итоги выборочного обследования «Влияние поведенческих факторов на состояние здоровья населения». 2008. - Росстат. Доступ: https://rosstat.gov.ru/folder/13721 (проверено 11.01.2021); Выборочное наблюдение поведенческих факторов, влияющих на состояние здоровья населения. 2013. - Poccmam. Доступ: https://rosstat.gov.ru/free doc/ new_site/zdor/sdp2013.bfs.publisher/index.html (проверено 11.01.2021); Выборочное наблюдение поведенческих факторов, влияющих на состояние здоровья населения. 2018. Poccmam. Доступ: https://rosstat.gov.ru/free_doc/new_site/ZDOR/Factors2018_2812/index. html (проверено 11.01.2021). 
ветствующее влияние таких весомых факторов, как наследственность, экология среды обитания и уровень развития здравоохранения.

Состояние здоровья, в свою очередь, оказывает влияние на трудовую деятельность граждан, их занятость и заработки [Кузьмич, Рощин 2007]. В данном случае следует говорить о двунаправленном влиянии здоровья и различных обстоятельств трудовой деятельности [Reeves, Stuckler 2016]. Результаты опроса показывают, что в период экономического кризиса, вызванного пандемией, наиболее сильно пострадали именно граждане, имеющие какие-либо проблемы со здоровьем. Среди тех респондентов, кто более негативно оценивает состояние своего здоровья, чаще встречаются ответы об ухудшении материального положения в связи с пандемией, о негативном влиянии кризиса на профессиональную деятельность (положение на работе ухудшилось или пришлось найти работу, которая хуже прежней). Например, среди тех респондентов, кто оценил состояние своего здоровья как «плохое» и «очень плохое», 58,9\% сообщили об ухудшении материального положения в связи с пандемией, в то время как в группе граждан, чья оценка своего здоровья значилась как «очень хорошее», доля пострадавших материально составила только 25\%, «хорошее» - 39,7\%, «удовлетворительное» $-44 \%$.

\section{Основные способы лечения занятых россиян}

Результаты медико-социологических исследований в области здоровья населения демонстрируют «отсталый характер поведенческих стратегий, когда большинство (2/3) взрослых прибегает к самолечению» [Осипов, Медик 2017: 164], игнорируя квалифицированную медицинскую помощь в случае заболевания.

Тем не менее можно отметить, что за последние годы увеличилось число граждан, которые в случае недомогания (болезни) обращаются к врачам, особенно рост заметен по результатам опроса текущего года. В данном случае имеются в виду обращения за лечением в государственные (муниципальные), ведомственные, частные медицинские организации или к частнопрактикующим специалистам. Если в 2008 г. в случае недомогания обычно обращались к врачам $52,2 \%$ занятого населения, то в 2013 г. - 62,0\%, а в 2020 г. - 81,4\% (см. рис. 3). При этом в текущем году $64,8 \%$ опрошенных имели опыт обращения в государственные (муниципальные) или ведомственные медицинские организации, а $34,9 \%$ - в негосударственные (платные, частные) медицинские организации (клиники), еще 5,1\% прибегали к помощи частнопрактикующих специалистов. Можно отметить, что в целом в течение последних лет нагрузка на медицинские организации постепенно увеличивается. Вместе с тем результаты исследования фиксируют снижение числа граждан, которые в случае недомогания (болезни) лечатся самостоятельно, применяя лекарства и «народные» средства. В 2008 г. таких респондентов было 65,5\%, в 2013 г. - 51,8\%, а в 2020 г. - 37,3\%.

По данным Росстата, отмечаются такие же разнонаправленные тенденции: снижение самолечения и повышение востребованности квалифицированной медицины. В 2008 г. о самостоятельном лечении в случае недомогания (болезни) сообщали 62,7\% лиц в возрасте 15 лет и старше, в 2013 г. - 60,5\%, в 2018 г. - 55,8\%. На обращение к врачам указали по годам исследования 56,4\%, $61,8 \%$ и $71,6 \%$ респондентов соответственно ${ }^{1}$.

\footnotetext{
${ }^{1}$ Краткие итоги выборочного обследования «Влияние поведенческих факторов на состояние здоровья населения». 2008. - Росстат. Доступ: https://rosstat.gov.ru/folder/13721 (проверено 11.01.2021); Выборочное наблюдение поведенческих факторов, влияющих на состояние здоровья населения. 2013. - Росстат. Доступ: https://rosstat.gov.ru/free_doc/new_site/zdor/ sdp2013.bfs.publisher/index.html (проверено 11.01.2021); Выборочное наблюдение поведенческих факторов, влияющих на состояние здоровья населения. 2018. - Pосстат. Доступ: https:// rosstat.gov.ru/free_doc/new_site/ZDOR/Factors2018_2812/index.html (проверено 11.01.2021).
} 


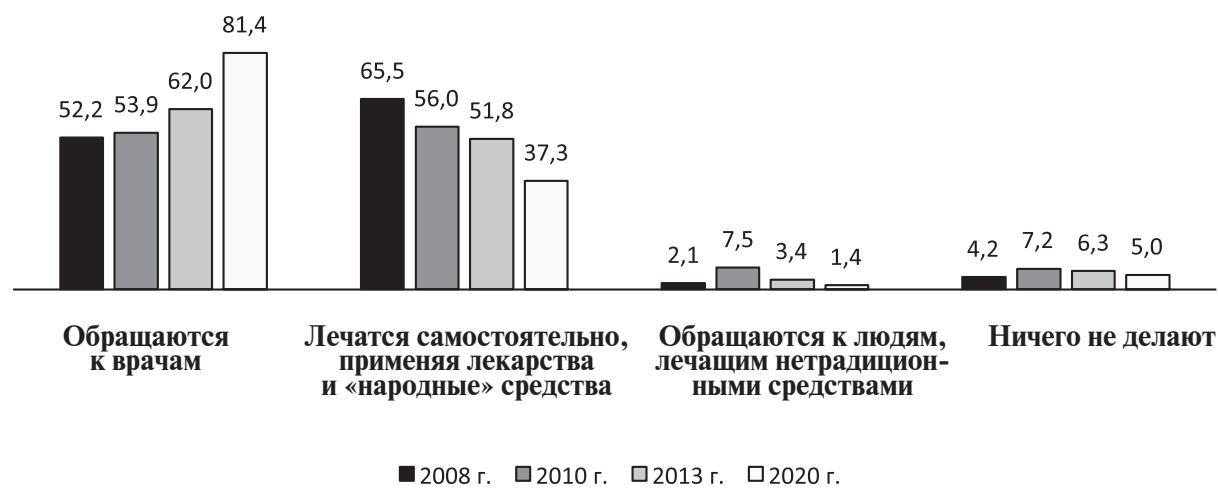

Примечание. Формулировка вопроса: «В случае недомогания (болезни) каким образом Вы обычно лечитесь?»

Рисунок 3. Способы лечения занятого населения в случае недомогания (болезни) (в \% от общего числа опрошенных)

Другое исследование Росстата (КОУЖ) показывает, что в 2018 г. треть опрошенных лиц в возрасте 15 лет и старше $(34,5 \%)$ имели случаи необращений в медорганизации при наличии потребности в медицинском осмотре или консультации с врачом. Причем в 2011 г. доля таких ответов была выше - 42,7\%. Свое решение не обращаться к врачам, как правило, респонденты объясняют тем, что предпочитают лечиться самостоятельно (74,5\% в 2011 г., 51,0\% в 2018 г.). Кроме того, нередко отмечается неудовлетворительная работа медицинских учреждений (в т.ч. большие очереди, невнимательное отношение, плохие условия приема и др.) и отсутствие надежды на эффективное лечение (отсутствие нужных специалистов, необходимых медикаментов или оборудования) ${ }^{1}$.

Результаты опроса занятого населения показывают, что способы лечения во многом определяются финансовыми возможностями респондентов и их половозрастными характеристиками. Например, мужчины реже стремятся попасть к врачу, да и в целом меньше занимаются самолечением в случае недомогания или болезни; они несколько больше женщин предпочитают вообще ничего не делать. По мере роста материального благополучия увеличивается число обращений в негосударственные (платные, частные) медицинские организации (клиники) и наоборот, по мере его снижения возрастает доля тех, кто лечится самостоятельно, применяя лекарства и «народные» средства.

Траектории лечения различных возрастных групп также имеют свои особенности (см. рис. 4). Традиционно с повышением возраста увеличивается доля обращающихся в государственные (муниципальные) или ведомственные медицинские организации. Граждане средних возрастных групп больше предпочитают лечиться самостоятельно, применяя лекарства и «народные» средства, или же обращаются в негосударственные (платные, частные) медицинские организации (клиники).

Добавим также, что к самостоятельному лечению с применением «народной» медицины чаще склонны жители сельских поселений, а обращения к услугам частных медицинских организаций как привычный способ лечения в данной группе опрошенных встречается реже, чем среди горожан.

1 Комплексное наблюдение условий жизни населения - 2018. - Росстат. Доступ: https://rosstat.gov.ru/free_doc/new_site/KOUZ18/index.html (проверено 11.01.2021). 


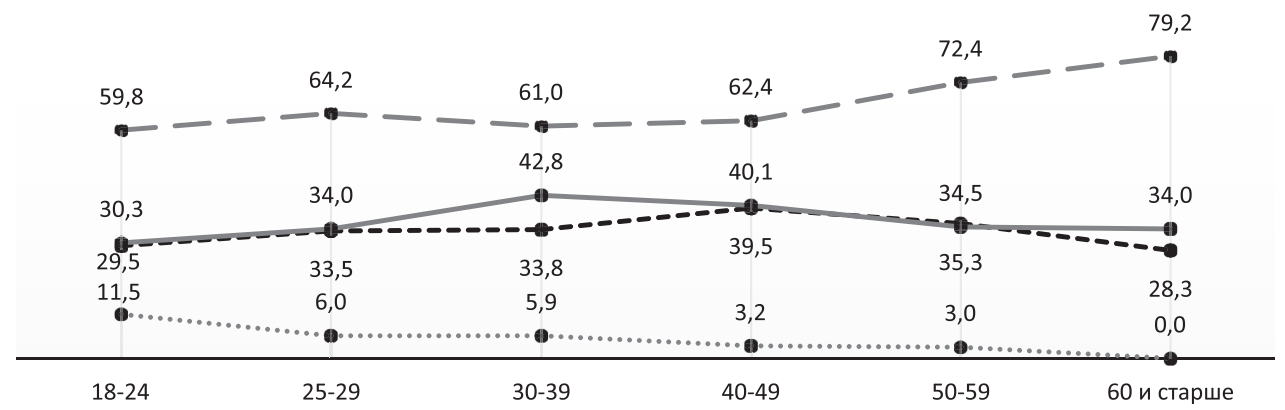

— - Обращаются в государственные (муниципальные) или ведомственные медицинские организации

- - - Обращаются в негосударственные (платные, частные) медицинские организации (клиники)

—- Лечатся самостоятельно, применяя лекарства и «народные» средства

....... Ничего не делают

Рисунок 4. Способы лечения в разных возрастных группах занятого населения в случае недомогания (болезни) (в \% по каждой выделенной категории)

\section{Заключение}

В целом можно сказать, что пандемия и связанный с ней экономический кризис оказывают влияние на структуру ценностей занятого населения. Согласно полученным данным, большую значимость для опрошенных приобретает их личное материальное положение, а также семейные ценности. Вопреки ожиданиям, в целом результаты не фиксируют роста значимости состояния здоровья в ряду основных ценностей в контексте сложной эпидемиологической ситуации и риска заболевания (за исключением возрастной группы 60 лет и старше, где значимость здоровья существенно возросла), хотя, безусловно, данная ценность является базовой и важной для россиян.

Результаты опроса показывают, что за последние десятилетия занятое население отмечает улучшение состояния своего здоровья. Однако наблюдаемая динамика не отражается на возрастной группе от 60 лет и старше.

Кроме того, данные исследования демонстрируют рост числа обращений занятого населения в различные медицинские учреждения в случае недомогания (болезни), что обусловливает увеличивающуюся нагрузку на систему здравоохранения. Все меньше граждан стремятся разрешить свои проблемы со здоровьем путем самостоятельного применения лекарств и «народных» средств. И это, безусловно, можно расценивать как положительный момент, поскольку самолечение может привести к развитию более тяжелых последствий для здоровья. Однако увеличивающаяся нагрузка на медицинские учреждения не соответствует текущим возможностям системы здравоохранения, которая испытывает значительные проблемы в связи с пандемией, на что следует обратить пристальное внимание органам государственного управления, чтобы учесть запросы общества на получение многосторонней качественной и доступной медицинской помощи. 


\section{Список литературы}

Безуглова М. 2020. Кризис в голове. Как адаптироваться и приобрести ценный опыт в условиях неопределенности. - Business Excellence. №10. Доступ: https://marinabezuglova.ru/BE_10_2020.pdf (проверено 15.05.2021).

Белова Н.И. 2016. Здоровье и практики его сохранения/поддержания. Жизненный мир россиян: 25 лет спустя (конеи, 1980-х - середина 2010-х гг.): научное издание (под ред. Ж.Т. Тощенко). М.: ЦСПиМ. С. 113-129.

Бойков В.Э. 2009. Здоровье как базовая ценность в сознании и быту российского населения. - Социология власти. № 2. С. 19-26.

Винокурова А.В. 2005. Основные подходы к изучению ценностей и ценностных ориентаций в отечественной социологии. - Труды Дальневосточного государственного технического университета. № 139. С. 53-58.

Гимпельсон В., Капелюшников Р. 2020. Рынок труда под натиском коронавируса. Доступ: https://www.hse.ru/mirror/pubs/share/369698959.pdf (проверено 15.05.2021).

Касьянов В.В., Гафиатулина Н.Х., Васьков М.А. 2020. Российское население в условиях режима самоизоляции: анализ депривационного влияния на социальное здоровье. - Государственное и муниципальное управление. Ученые записки. № 2. С. 204-208.

Козырева П.М., Смирнов А.И. 2020. Динамика самооценок здоровья россиян: актуальные тренды постсоветского периода. - Социс. Социологические исследования. № 4. С. 70-81.

Кузьмич О.С., Рощин С.Ю. 2007. Влияние здоровья на заработную плату и занятость: эмпирические оценки отдачи от здоровья: препринт WP15/2007/02. М.: ГУ ВШЭ. 60 с.

Максименко А.А. 2011. Социологическая интерпретация понятия «ценность». - Вестник КГУ им. Н.А. Некрасова. № 2. С. 284-291.

Назарова И.Б. 2003. Здоровье российского населения: факторы и характеристики (90-е годы). - Социс. Социологические исследования. № 11. С. 57-69.

Осипов А.М., Медик В.А. 2017. Медико-социологические аспекты совершенствования системы охраны здоровья. - Здоровье - основа человеческого потенциала: проблемы и пути их решения. Т. 12. № 1. С. 163-169.

Покида А.Н., Зыбуновская Н.В. 2010. Здоровый образ жизни как социальная ценность и реальная практика. - Социология власти. № 7. С. 48-55.

Reeves A., Stuckler D. 2016. Политика на рынке труда и здоровье: структурированный обзор двунаправленных связей. -Панорама общественного здравоохранения: журнал Европейского регионального бюро ВОЗ. Т. 2. Вып. 2. С. 147-159. Доступ: https://apps.who.int/iris/handle/10665/325673 (проверено 15.05.2021). 
POKIDA Andrei Nikolaevich, Cand.Sci. (Soc.), Director of the Research Center for Social and Political Monitoring, School of Public Policy, Russian Presidential Academy of National Economy and Public Administration (RANEPA) (82 Vernadskogo Ave, Moscow, Russia, 119571; pokida@ranepa.ru)

ZYBUNOVSKAYA Natal 'ya Vladimirovna, Research Fellow at the Research Center for Social and Political Monitoring, School of Public Policy, Russian Presidential Academy of National Economy and Public Administration (RANEPA) (82 Vernadskogo Ave, Moscow, Russia, 119571; nzyb@ ranepa.ru)

GAZIEVA Inna Aleksandrovna, Cand.Sci. (Soc.), Director of the Center for General Academic Educational Initiatives, Institute for Organizational Development and Strategic Initiatives, Russian Presidential Academy of National Economy and Public Administration (RANEPA) (82 Vernadskogo Ave, Moscow, Russia, 119571; gazieva-ia@ranepa.ru)

\title{
SELF-ASSESSMENT OF THE HEALTH STATE OF EMPLOYED RUSSIANS AND BASIC METHODS OF TREATMENT
}

\begin{abstract}
The aim of the article is to consider self-assessments of health and the main treating methods of employed Russians in the changed reality due to the pandemic. The empirical basis of the study was the results of a sociological survey of the employed Russian population, conducted in 2020. The results of the study demonstrate a tendency for the growth of positive self-assessments of the health of employed Russians over the last decades, which, however, does not apply to the oldest generation, which assess their health even worse than in previous years. The authors reveal that during the period of the economic crisis caused by the pandemic, the most severely affected in the professional and material spheres were citizens who had any health problems. There is a decrease in the popularity of self-medication and an increase in the number of calls of the employed population to various medical institutions in case of malaise (illness), which causes an increasing burden on the health care system.

The article is written on the base of the RANEPA state assignment research program.
\end{abstract}

Keywords: health, COVID-19 pandemic, self-assessment of health, methods of treatment, values 